\title{
Pengungkapan Corporate Social Responsibility Terhadap Agresivitas Pajak
}

\author{
Wahyu Alif Kurniawan ${ }^{1}$ dan Darti Djuharni ${ }^{21}$ \\ ${ }^{1,2}$ Sekolah Tinggi Ilmu Ekonomi (STIE) Malangkuçeçwara, Jl. Candi kalasan, Malang, Indonesia.
}

Doi: http://

Abstract

The purpose of this study aims to analyze the disclosure of Corporate Social Responsibility (CSR) on corporate tax aggressiveness. The independent variable of this study is corporate social responsibility (CSR) using the dummy method and based on the standard GRI G-4 / GRI index and the dependent variable of this study is the tax aggressiveness required with an effective tax rate proxy (ETR). This study uses control variables including profitability, leverage, capital intensity, and inventory intensity. The study uses secondary data conducted on manufacturing companies listed on the Indonesia Stock Exchange in 2016-2018 and the study sample was obtained by 11 companies. The research method used uses multiple linear regression with the help of SPSS 22 software. The results of this study prove that the disclosure of Corporate Social Responsibility is not significant for tax aggressiveness.

Type Article : Empiris

Keywords: Tax Aggressiveness; Corporate Social Responsibility; Profitability; Leverage; Capital Intensity; and Inventory Intensity.

\section{Pendahuluan}

\subsection{Latar Belakang Masalah}

Permasalahan pajak di Indonesia sudah lebih dari satu dekade tetapi sampai saat ini belum dapat mencapai target yang ditetapkan (Saputro, 2019). Lebih lanjut dikatakannya target penerimaan negara dari pajak setiap tahun selalu dievaluasi, dan berbagai upaya telah dilakukan pemerintah, mulai dari perubahan undang-undang pajak perseroan di tahun 1970 sampai dengan pembaruan dalam sistem pemungutan pajak di tahun 1984. Oleh karena itu, kesadaran masyarakat dalam membayar pajak akan sangat membantu untuk pencapaian target tersebut.

Penerimaan pajak yang diperoleh dari laporan Kementerian Keuangan tahun 2019 tampak pada tabel berikut (Indonesia, 2019).

\footnotetext{
${ }^{1}$ Kontak penulis:

Email:

Afiliasi:
} 
Tabel 1 Penerimaan Pajak (2015-2019)

\begin{tabular}{crr}
\hline Tahun & Pencapaian (Triliun Rp) & \multicolumn{1}{c}{ Kenaikan (\%) } \\
\hline 2015 & 1.240 .4 & $8.2 \%$ \\
\hline 2016 & $1.285,0$ & $3.6 \%$ \\
\hline 2017 & $1.472,7$ & $14.6 \%$ \\
\hline 2018 & $1.618,1$ & $10 \%$ \\
\hline 2019 & $1.786,4$ & $10.4 \%$ \\
\hline
\end{tabular}

Sumber: https://www.kemenkeu.go.id/apbn2019

Hasil penerimaan negara dari pajak sebagaimana tampak pada tabel 1, jika dibandingkan dengan rencana strategis berdasarkan laporan kinerja direktorat jenderal pajak untuk periode 2015- 2019 belum memenuhi target yang ditetapkan. Target yang ditetapkan adalah $1.294 \mathrm{~T}$, $1.512 \mathrm{~T}, 1.737 \mathrm{~T}, 2.007 \mathrm{~T}$, dan $2.329 \mathrm{~T}$ (Utomo, 2019). Belum tercapainya target penerimaan negara dari sektor pajak memunculkan pertanyaan apakah pemerintah belum mampu memaksimalkan pemungutan pajak dari masyarakat ataukah karena ada berbagai upaya yang dilakukan wajib pajak untuk meminimalkan pajaknya (Wiguna \& Jati, 2017).

Pajak yang dapat dijadikan faktor motivasi dalam berbagai keputusan perusahaan mendorong manajerial untuk meminimalkannya melalui kegiatan agresivitas pajak yang merupakan hal yang umum terjadi di lingkungan perusahaan di seluruh dunia (Lanis \& Richardson, 2012). Penghindaran pajak yang banyak dilakukan oleh perusahaan ditujukan untuk memperoleh keuntungan yang lebih besar (Pradnyadari \& Rohman, 2015).

Upaya untuk menghindari pajak atau agresivitas pajak yang dilakukan perusahaan perlu mendapat perhatian serius karena dapat menurunkan kepercayaan masyarakat terhadap kinerja perusahaan, oleh karena itu perusahaan mengungkap tahunan tanggung jawab sosial melalui laporan tahunan untuk mengembalikan kepercayaan masyarakat. Pembuatan laporan tanggung jawab sosial ini merupakan beban tersendiri bagi perusahaan, sehingga untuk meringankan beban, agresivitas pajak merupakan alternatif yang dilakukannya (Pradnyadari \& Rohman, 2015).

Tanggung jawab sosial dan lingkungan perlu diperhatikan perusahaan dalam menjalankan aktifitas yang berkaitan dengan sumber daya alam sesuai dengan UU nomor 40 tahun 2007 wajib melaksanakan tanggung jawab sosial dan lingkungan atau lebih dikenal dengan istilah Corporate Social Responsibility (CSR). Perusahaan yang melakukan pengungkapan CSR memberikan dampak yang positif, namun pengungkapan tersebut dijadikan alasan untuk melakukan agresivitas pajak melalui celah pemanfaatan yang ada dalam peraturan pajak. Keterkaitan antara pengungkapan CSR dengan agresivitas pajak terletak pada tujuan utama perusahaan yaitu memperoleh laba tanpa menghilangkan tanggung jawab sosial dan lingkungan, sehingga semakin besar laba yang diperoleh perusahaan akan semakin tinggi penghasilan yang dikenakan pajak.

Beberapa penelitian sebelumnya yang membahas CSR dengan agresivitas pajak disampaikan antara lain oleh : Nurcahyono and Kristiana (2019) yang mengungkapkan adalah pengungkapan CSR berpengaruh negatif terhadap agresivitas pajak. Hal senada disampaikan oleh (Fionasari, Savitri, \& Andreas, 2017) mereka mengungkapkan bahwa tara CSR tidak berpengaruh terhadap agresvitas pajak. Begitu juga yang disampaikan oleh Pradnyadari and Rohman (2015) bahwa pengungkapan CSR berpengaruh negative terhadap agresivitas pajak.

Lanis and Richardson (2012) menyusun sejumlah analisis untuk mengetahui apakah pendekatan perusahaan untuk CSR berhubungan dengan tingkat agresivitas pajak, bahwa semakin tinggi tingkat pengungkapan CSR dari suatu perusahaan, semakin rendah tingkat 
agresivitas pajak perusahaan tersebut. Mereka menemukan bahwa pengungkapan CSR juga berpengaruh negatif terhadap agresivitas pajak.

Berdasarkan uraian di atas, peneliti mencoba mengkaji kembali topik yang sama dengan kondisi yang ada di Indonesia, dengan menggunakan variabel profitabilitas, leverage, capital intensity, sedangkan inventory intensity digunakan sebagai variabel kontrol Kajian ini menggunakan wajib pajak badan yaitu perusahaan manufaktur di Indonesia yang melaporkan kegiatannya di Bursa Efek Indonesia selama tiga tahun berturut-turut yaitu tahun 2016-2018 Dengan demikian penelitian ini ditujukan untuk menganalisis pengaruh pengungkapan Corporate Social Responsibility terhadap agresivitas pajak.

\section{Tinjauan Pustaka}

\subsection{Teori Legitimasi}

Legitimasi masyarakat merupakan faktor strategis bagi perusahaan dalam rangka mengembangkan perusahaan kedepannya. Hal itu, dapat dijadikan sebagai wahana untuk mengkontruksi strategi perusahaan, terutama terkait dengan upaya memposisikan diri ditengah lingkungan masyarakat yang semakin maju. Legitimasi merupakan keadaan psikologis keberpihakan orang dan kelompok orang yang sangat peka terhadap gejala lingkungan sekitarnya baik fisik maupun non fisik (Hadi, 2011).

Teori legitimasi menjelaskan perusahaan melakukan kegiatan usaha dengan batasanbatasan yang ditentukan oleh norma-norma, nilai-nilai sosial dan reaksi terhadap batasan tersebut mendorong pentingnya perilaku organisasi dengan memperhatikan lingkungan. Teori legitimasi juga menjelaskan kontrak sosial dengan masyarakat, kelangsungan hidup perusahaan akan terancam jika masyarakat merasa organisasi telah melanggar kontrak sosialnya.

\subsection{Teori Sinyal}

Teori sinyal dikembangkan oleh Ross (1977) menyatakan bahwa pihak eksekutif perusahaan memiliki informasi lebih baik mengenai perusahaannya dan akan terdorong untuk menyampaikan informasi tersebut kepada calon investor agar harga saham perusahaannya meningkat. Teori Sinyal membahas mengenai dorongan perusahaan untuk memberikan informasi kepada pihak eksternal.Informasi yang wajib perusahaan ungkapkan adalah informasi mengenai tanggung jawab sosial perusahaan atau yang sering disebut dengan corporate social responsibility

\subsection{Teori Stakeholder}

Teori stakeholder menunjukkan bahwa keberhasilan bisnis terletak pada kemampuan perusahaan untuk mempertahankan hubungan yang saling percaya dan saling menghormati dengan berbagai stakeholder, yang meliputi pelanggan, pemasok, karyawan, masyarakat, dan pemerintah (Freedman, 2003).

Menurut Ghozali(2013) teori stakeholder mengatakan bahwa perusahaan bukanlah entitas yang hanya beroperasi untuk kepentingan sendiri namun harus memberikan manfaat bagi stakeholder-nya. Dengan demikian, keberadaan suatu perusahaan sangat dipengaruhi oleh dukungan yang diberikan oleh stakeholder kepada perusahaan tersebut.

\section{Agresivitas Pajak}

Lanis and Richardson (2012) mendefinisikan agresivitas pajak sebagai kegiatan manajerial yang dilakukan melalui perencanaan pajak dengan memanipulasi penghasilan kena pajak baik dengan cara legal atau illegal. Tindakan agresivitas pajak dapat menimbulkan risiko bagi perusahaan seperti denda atau hilangnya reputasi perusahaan. Hal ini terjadi jika penghindaran pajak tersebut melanggar batasan perpajakan yang kemudian dapat digolongkan sebagai 
penggelapan pajak. Salah satu cara untuk mengetahui perusahaan bertindak agresif terhadap pajak yaitu mengukur dengan proksi Effective Tax Rate (ETR).

\section{2. $\quad$ Corporate Social Responsibility}

\section{1.}

Pengertian (CSR) diatur dalam Pasal 1 ayat (3) Undang-undang Nomor 40 Tahun 2007 tentang Perseroan Terbatas. Tanggung Jawab Sosial Perusahaan adalah komitmen perseroan untuk berperan serta dalam pembangunan ekonomi berkelanjutan guna meningkatkan kualitas kehidupan dan lingkungan yang bermanfaat, baik bagi perseroan sendiri, komunitas setempat, maupun masyarakat pada umumnya. CSR juga dapat digunakan perusahaan agar lebih unggul dari pesaing dalam hal mendapatkan keuntungan. Begitu sebuah perusahaan dalam suatu industri telah berhasil menerapkan kebijakan CSR, perusahaan pesaing mungkin terpaksa untuk terlibat juga dalam aktivitas CSR. Apabila perusahaan pesaing tidak menerapkan CSR, maka perusahaan pesaing tersebut terancam kehilangan loyalitas konsumen. Adapun rumus untuk menghitung CSRI sebagai berikut:

\section{Profitabilitas (ROA)}

$$
\text { CSRIi }=\frac{\sum \mathrm{Xyi}}{\mathrm{ni}}
$$

Profitabilitas menunjukkan kemampuan perusahaan untuk menghasilkan laba atau hasil akhir operasional perusahaan selama periode tertentu. Laba dijadikan indikator bagi para stakeholder untuk menilai seberapa jauh kinerja manajemen dalam mengelola suatu perusahaan. Perusahaan yang mempunyai profitabilitas tinggi dapat menarik investor untuk menanamkan modalnya di perusahaan tersebut karena menunjukkan keberhasilan kinerja manajemen dalam mengelola perusahaan. Sebaliknya, jika profitabilitas rendah maka investor cenderung tidak tertarik dalam menanamkan modalnya(Sudana \& Airlindania, 2011).

Profitabilitas didefinisikan sebagai ukuran yang mencerminkan penggunaan modal dalam suatu perusahaan atau menggambarkan kemampuan perusahaan dalam memperoleh laba yang dihasilkan dari total aset yang dimiliki. Lanis and Richardson (2012) menggunakan ROA sebagai proksi ukur profitabilitas, yaitu sebagai berikut :

$$
R O A=\frac{\text { Laba Bersih Setelah Pajak }}{\text { Total Asset }}
$$

\section{Leverage}

leverage sebagai penggunaan aset atau dana dimana untuk penggunaan tersebut perusahaan harus menutup biaya tetap atau membayar beban tetap. Leverage merupakan salah satu rasio keuangan yang menggambarkan hubungan antara hutang perusahaan terhadap modal ataupun aset perusahaan.

Leverage menggambarkan proporsi hutang jangka panjang terhadap total aset yang dimiliki perusahaan. Hal ini dilakukan untuk mengetahui keputusan pendanaan yang dilakukan oleh perusahaan tersebut. Leverage menurut Lanis and Richardson (2012) dihitung dari:

$$
L E V=\frac{\text { Hutang Jangka panjang }}{\text { Total Asset }}
$$

\section{Capital Intensity}


Capital Intensity mencerminkan seberapa besar kekayaan perusahaan yang diinvestasikan dalam bentuk aset tetap. Aset tetap dalam hal ini mencakup bangunan, pabrik, peralatan, mesin dan berbagai properti lainnya. Capital Intensity berhubungan dengan agresivitas pajak karena akumualsi depresiasi yang disesuaikan dengan masa aset (Gupta \& K, 1997)

Capital Intensity menggambarkan seberapa besar aset perusahaan yang diinvestasikan dalam bentuk aset tetap. Capital intensity menurut Lanis and Richardson (2012) dihitung dari

$$
C I N T=\frac{\text { Total Aset Tetap Bersih }}{\text { Total Asset }}
$$

\section{Inventory Intensity}

Inventory Intensity atau bisa disebut juga dengan intensitas persediaan merupakan salah satu komponen penyusun komposisi aktiva yang diukur dengan membandingkan antara total persediaan dengan total aset yang dimiliki perusahaan. Perusahaan yang memiliki intensitas persediaan tinggi biasanya memiliki ETR yang tinggi. Hal ini karena perusahaan yang berinvestasi dalam bentuk persediaan tidak dapat melakukan hal serupa ketika perusahaan memiliki intensitas modal yang tinggi yakni dalam hal depresiasi yang dapat dijadikan pengurang penghasilan pajak (Gupta \& K, 1997).

Capital Intensity menggambarkan seberapa besar aset perusahaan yang diinvestasikan dalam bentuk aset tetap. Capital intensity menurut Lanis and Richardson (2012) dihitung dari

$$
C I N T=\frac{\text { Total Aset Tetap Bersih }}{\text { Total Asset }}
$$

\section{Kerangka Penelitian}

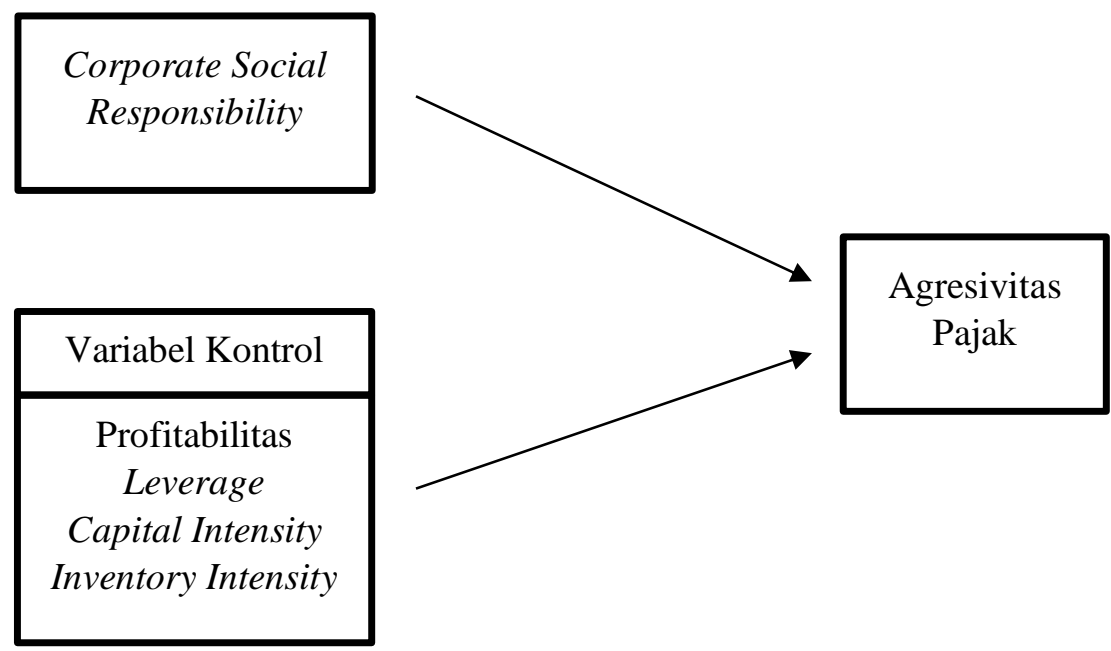

Lanis and Richardson (2012) menyatakan bahwa sulit untuk membedakan antara CSR yang dilakukan dengan motif altruistik dengan CSR yang dilakukan dengan tujuan untuk menguntungkan reputasi perusahaan. Sebaliknya, banyak aksi perusahaan yang dilakukan dengan motif ganda. Oleh karena itu penting dalam mempertimbangkan bagaimana CSR dapat mempengaruhi agresivitas pajak tanpa membuat setiap upaya untuk membedakan antara tindakan yang diambil karena perusahaan benar-benar ingin bertanggung jawab maupun tindakan yang diambil karena tujuan tertentu. Dengan demikian, semakin tinggi tingkat 
pengungkapan CSR yang dilakukan oleh perusahaan, diharapkan perusahaan tersebut semakin tidak agresif terhadap pajak. Hal ini karena apabila perusahaan yang menjalankan CSR bertindak agresif terhadap pajak, maka akan membuat perusahaan tersebut kehilangan reputasi di mata stakeholdernya dan akan menghilangkan dampak positif yang terkait dengan kegiatan CSR yang telah dilakukan. Oleh karena itu, hipotesis penelitian ini adalah :

HO : CSR tidak berpengaruh terhadap agresivitas pajak

H1 : CSR berpengaruh negatif terhadap agresivitas pajak

\section{Metodologi Penelitian}

Penelitian ini dilakukan dengan pendekatan kuantitatif, karena akan menguji pengaruh independen terhadap dependen dalam hal ini adalah CSR dan agresivitas pajak. Selain itu penelitian termasuk jenis penelitian asosiatif karena mencari hubungan antara dua variabel atau lebih (Kurniawan \& Puspitaningtyas, 2016). Data dikumpulkan melalui laporan keuangan perusahaan manufaktur yang terdaftar di BEI pada periode 2016-2018 yaitu sebanyak 187 perusahaan. Dari jumlah populasi tersebut ditentukan kriteria sampelnya yaitu yang membuat laporan keuangan secara berturut-turut selama tiga tahun, tidak mengalami kerugian selama periode 2016-2018, memiliki nilai ETR 0-1, dan memiliki nilai asset positif selama periode tersebut.

Adapun variabel yang dianalisis dalam penelitian ini adalah agresivitas pajak sebagai variabel terikat (dependen), lalu CSR sebagai variabel bebas (independent), serta ROA, leverage, capital intensity, inventory intensity sebagai variabel kontrol. Berdasarkan kriteria yang ditentukan ditemukan 11 perusahaan yang memenuhi syarat, sehingga jumlah sampel yang digunakan adalah 33 amatan terhadap laporan keuangan tiga tahun dari 11 perusahaan. Kesebelas perusahaan yang dimaksud tampak pada tabel berikut ini.

Tabel 1 Perusahaan Manufaktur

\begin{tabular}{cll}
\hline No & Kode & Perusahaan \\
\hline 1 & INTP & Indocement \\
\hline 2 & SMGR & Semen Indonesia \\
\hline 3 & WTON & Wijaya Karya Beton \\
\hline 4 & ASII & Astra International \\
\hline 5 & WSBP & Waskita Beton Precast \\
\hline 6 & SMBC & Solusi Bangun Indonesia \\
\hline 7 & UNVR & Unilever Indonesia \\
\hline 8 & INKP & Indah Kiat Pulp \& Papper \\
\hline 9 & TKIM & Pabrik Kertas Tjiwi Kimia \\
\hline 10 & CPIN & Charoen Phokpad Indonesia \\
\hline 11 & FPNI & Lotte Chemical Titan \\
\hline
\end{tabular}

Berdasarkan informasi laporan keuangan selama tiga tahun dari sebelas perusahaan yang ditunjukkan pada tabel 1 di atas, maka tahapan analisis yang dilakukan adalah: melakukan analisis deskriptif dan analisis regresi berganda dengan menggunakan rumus,

$$
\text { TAGit }=0,021+0,250 \mathrm{X}+0,002 \mathrm{C} 1+1,108 \mathrm{C} 2+0,25 \mathrm{C} 3+(-0,27 \mathrm{C} 4)+\mathrm{e}
$$

\section{Hasil}

Berdasarkan tahapan analisis yang telah diuraikan sebelumnya, maka hasil analisis data diuraikan sebagai berikut.

\subsection{Analisis Deskriptif}


Berdasarkan pengujian yang dilakukan dengan menggunakan SPSS, diperoleh hasil analisis statistik yang menunjukkan karakteristik setiap variabel. Hasil analisis deskriptif menunjukkan nilai minimum, maksimum, rata-rata (mean) dan standar deviasi sebagaimana tampak pada tabel 2 berikut ini.

Tabel 2. Analisis Deskriptif

\begin{tabular}{|l|r|r|r|r|r|}
\hline \multicolumn{7}{|c|}{ Descriptive Statistics } \\
\hline CSR & N & Minimum & Maximum & \multicolumn{1}{c|}{ Mean } & \multicolumn{1}{c|}{$\begin{array}{c}\text { Std. } \\
\text { Deviation }\end{array}$} \\
\hline Pajak & 33 &, 10 &, 81 &, 3952 &, 23575 \\
\hline ROA & 33 &, 00 & 7,68 &, 4507 & 1,30346 \\
\hline Leverage & 33 & $-4,44$ & 46,66 & 8,3857 & 11,32534 \\
\hline CINT & 33 &, 00 &, 46 &, 1636 &, 14060 \\
\hline INVENT & 33 &, 14 &, 84 &, 4745 &, 18574 \\
\hline $\begin{array}{l}\text { Valid N } \\
\text { (listwise) }\end{array}$ & 33 &, 00 &, 30 &, 1191 &, 07388 \\
\hline
\end{tabular}

Penelitian ini menggunakan satu variabel independen yang diprediksi berpengaruh negatif terhadap agresivitas pajak. Variabel dependen agresivitas pajak menunjukkan nilai rata-rata 0,39 dan standar deviasi 0,23. Nilai rata-rata merupakan representasi yang baik atas keseluruhan data, karena nilai rata-rata jauh lebih besar dari standar deviasi. Variabel independen yang digunakan adalah CSR yang diukur dengan GRI standar/GRI-G4. Variabel CSR menunjukkan rata-rata 0,45 dan standar deviasi 1,30 dapat disimpulkan nilai rata-rata merupakan representasi yang baik atas keseluruhan data, karena nilai rata-rata jauh lebih besar dari standar deviasi.

Analisis Regresi Berganda

Tabel 3. Analisis Regresi Berganda

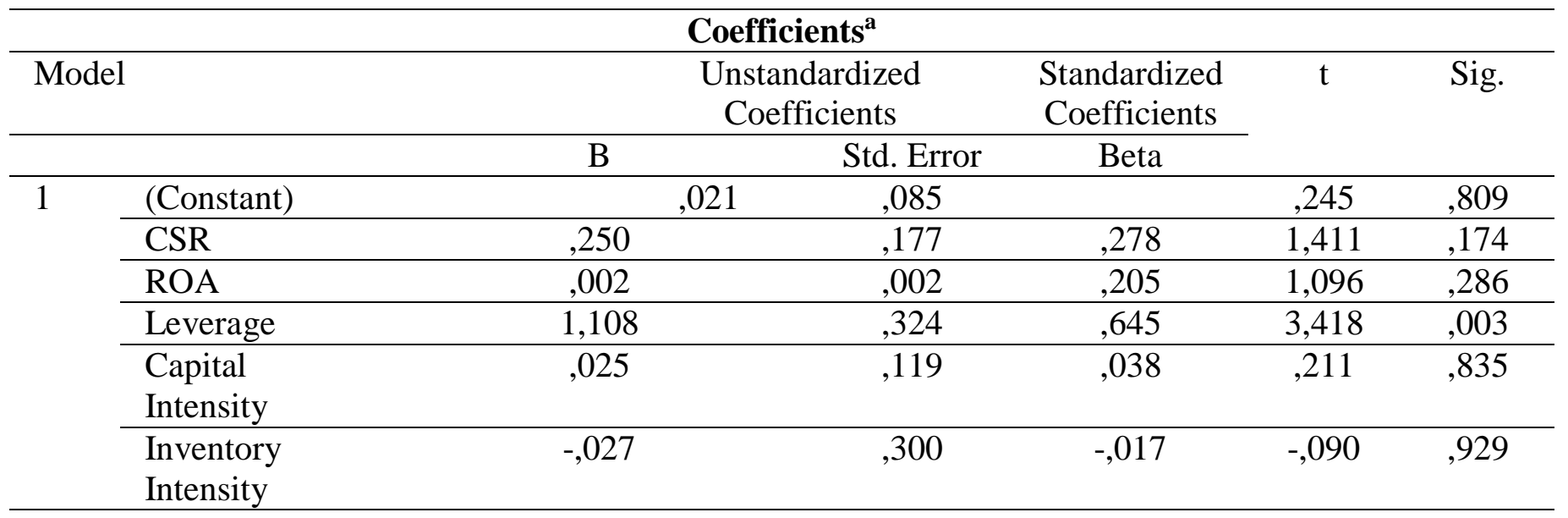

a. Dependent Variable: Pajak

Variabel kontrol ROA menunjukkan hasil rata-rata 8,38 dan standar deviasi 11,3. Variabel kontrol leverage menunjukkan rata-rata 0,16 dan standar deviasi 0,14 . Variabel kontrol capital 
intensity menunjukkan rata-rata 0,47 dan standar deviasi 0,18 . Variabel kontrol inventory intensity menunjukkan rata-rata 0,11 dan standar deviasi 0,07 .

\subsection{Uji Determinasi}

Tabel 4. Uji Determinasi

\begin{tabular}{lcccc}
\hline \multicolumn{4}{c}{ Model Summary $^{\mathbf{b}}$} \\
\hline Model & $\mathrm{R}$ & R Square & Adjusted R Square & $\begin{array}{c}\text { Std. Error of the } \\
\text { Estimate }\end{array}$ \\
\hline 1 &, $670^{\text {a }}$ &, 449 &, 311 &, 106543957 \\
$\begin{array}{l}\text { a. Predictors: (Constant), Inventory Intensity, Capital Intensity, ROA, Leverage, CSR } \\
\text { b. Dependent Variable: Pajak }\end{array}$ & & & \\
\hline
\end{tabular}

Tabel 4 menunjukkan nilai koefisien determinasi (Adjusted $R$ Square) sebesar 0,311 yang berarti nilai variabilitas variabel dependen yang dapat dijelaskan oleh variabilitas variabel independen sebesar $31,1 \%$. Sehingga dapat disimpulkan bahwa variabel independen mampu menjelaskan variabel dependennya sebesar 31,1\%sedangkan sisanya 68,9\%(100\% - 31,1\%) dijelaskan oleh variabel lain yang tidak dimasukkan dalam dalam model regresi. Std.Error of The Estimate (SEE) sebesar 0,106

\subsection{Ujif}

Tabel 5. Uji f

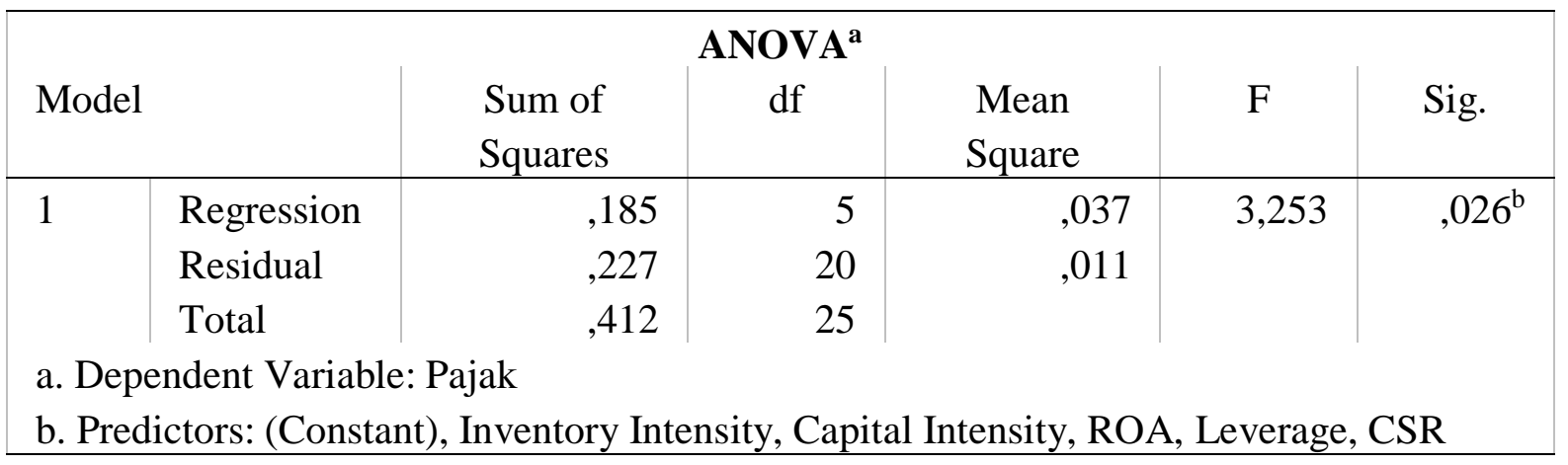

Berdasarkan tabel 5 diketahui nilai signifikansi untuk pengaruh $\mathrm{X} 1, \mathrm{C} 1, \mathrm{C} 2, \mathrm{C} 3, \mathrm{C} 4$ secara simultan terhadap Y adalah sebesar $(0,026<0,05)$, F tabel dalam tabel tersebut lebih besar dari F hitung $(3,253>2,57)$ sehingga dapat disimpulkan terdapat pengaruh variabel X1, C1, C2, C3 ,C4 terhadap variabel $\mathrm{Y}$, bahwa seluruh variabel independen yang dihasilkan dalam penelitian secara bersama-sama mempengaruhi variabel dependen, yaitu agresivitas pajak. 
Tabel 6 Uji t

Coefficients $^{\mathbf{a}}$

\begin{tabular}{|c|c|c|c|c|c|c|}
\hline \multicolumn{2}{|c|}{ Model } & \multicolumn{2}{|c|}{$\begin{array}{l}\text { Unstandardized } \\
\text { Coefficients }\end{array}$} & \multirow{2}{*}{$\begin{array}{c}\text { Standardize } \\
\mathrm{d} \\
\text { Coefficient } \\
\mathrm{s} \\
\text { Beta }\end{array}$} & \multirow[t]{2}{*}{$\mathrm{t}$} & \multirow[t]{2}{*}{ Sig. } \\
\hline & & B & Std. Error & & & \\
\hline \multirow[t]{7}{*}{1} & (Constant) &, 021 & 085 & & 245 & 809 \\
\hline & CSR &, 250 & ,177 & 278 & 1,411 & 174 \\
\hline & ROA & 002 & 002 & 205 & 1,096 & ,286 \\
\hline & Leverage & 1,108 & ,324 &, 645 & 3,418 & 003 \\
\hline & Capital & 025 &, 119 & ,038 & ,211 & ,835 \\
\hline & Intensity & & & & & \\
\hline & $\begin{array}{l}\text { Inventory } \\
\text { Intensity }\end{array}$ &,- 027 & ,300 & -,017 &,- 090 & 929, \\
\hline \multicolumn{7}{|c|}{ a. Dependent Variable: Pajak } \\
\hline
\end{tabular}

Berdasarkan hasil tabel 6 uji t pada model di atas dapat disimpulkan bahwa variabel independen corporate social responsibility (CSR) tidak berpengaruh signifikan terhadap agresivitas pajak karena memiliki tingkat signifikansi yang lebih besar dari $0,05(0,174>0,05)$ dan hasil $t$ tabel menunjukkan lebih besar dari t hitung $(0,245<1,701)$ dengan demikian pengujian menunjukkan $\mathrm{H} 0$ diterima.

Variabel kontrol profitabilitas (ROA) tidak berpengaruh signifikan terhadap agresivitas pajak karena memiliki tingkat signifikansi yang lebih besar dari $0,05(0,286>0,05)$ dan menunjukkan $\mathrm{t}$ tabel lebih besar dari $\mathrm{t}$ hitung $(1,411<1,701)$. Variabel kontrol leverage (LEV) berpengaruh signifikan terhadap agresivitas pajak karena memiliki signifikansi yang lebih kecil dari $0,05(0,03<0,05)$ dan menunjukkan t tabel lebih besar dari t hitung $(3,481>1,701)$. Variabel kontrol capital intensity (CINT) tidak terdapat pengaruh signifikan terhadap agresivitas pajak yang lebih besar dari $0,05(0,835>0,05)$ dan $t$ tabel lebih besar dari t hitung $(0,211<1,701)$. Variabel kontrol inventory intensity (INVENT) tidak berpengaruh terhadap agresivitas pajak karena memiliki signifikansi lebih besar dari 0,567 $(0,929>0,05)$ dan $t$ tabel lebih besar dari t hitung $(-0,90<1,701)$.

\section{Diskusi}

Lanis and Richardson (2012) mengatakan bahwa perusahaan dengan tingkat pengungkapan CSR lebih tinggi, memiliki agresivitas pajak yang lebih rendah. Berdasarkan Hasil penelitian ini membuktikan jika corporate social responsibilty tidak berpengaruh terhadap agresivitas pajak. Dapat diartikan bahwa apabila nilai pengungkapan CSR besar, maka belum tentu perusahaan akan semakin tidak agresif. Hubungan tidak berpengaruh antara CSR dan agresivitas pajak juga diperoleh Jessica \& Toly (2014) serta Makhfudloh, Herawati, and Wulandari (2018). Setelah melakukan analisis dari hasil pengujian, menunjukkan bahwa CSR tidak memiliki pengaruh terhadap agresivitas pajak dikarenakan informasi CSR yang diungkapkan dalam laporan belum tentu sesuai dengan kondisi sebenarnya. Sehingga tingkat pengungkapan kegiatan tanggung jawab sosial dalam laporan tahunan perusahaan tidak dijadikan jaminan rendahnya tindakan agresivitas pajak yang dilakukan perusahaan. 
Penelitian ini tidak mendukung penelitian dari Nurcahyono and Kristiana (2019) serta Pradnyadari and Rohman (2015) menemukan bahwa perusahaan yang bertanggung jawab secara sosial melakukan lebih sedikit kegiatan perencanaan pajak dibandingkan dengan perusahaan yang tidak bertanggung jawab secara sosial. Dengan demikian, dapat disimpulkan bahwa CSR tidak berpengaruh signifikan terhadap agresivitas pajak.

Variabel kontrol dalam penelitian ini adalah profitabilitas, leverage, capital intensity, inventory intensity juga digunakan dalam penelitian sebelumnya. Variabel kontrol profitabilitas (ROA) berpengaruh negatif dan signifikan terhadap agresivitas pajak, terlihat dari signifikansinya lebih dari 0,05 . Pengaruh variabel kontrol profitabilitas terhadap CSR yang diukur dengan ROA yaitu membandingkan antara laba bersih setelah pajak denga total aset, tidak berpengaruh terhadap ETR. Besar kecilnya perusahaan tidak dapat dijadikan acuan terhadap agresivitas pajak. Hal ini dikarenakan baik perusahaan kecil atau besar berusaha memberikan pengungkapan sosial yang dibutuhkan masyarakat dan investor. Profitabilitas tidak berpengaruh terhadap pembayaran pajak artinya perusahaan memiliki profitabilitas bukan berarti perusahaan tersebut juga tinggi dalam tingkat pembayaran pajak. Penelitian ini sejalan dengan jessica \& toly (2014) bahwa profitabilitas dengan proksi ROA tidak berpengaruh signifikan terhadap agresivitas pajak.

Pengaruh variabel kontrol leverage berpengaruh terhadap agresivitas pajak dengan menunjukkan signifikansi kurang dari 0,05, sehingga diketahui variabel leverage berpengaruh signifikan. Hal tersebut sejalan dengan hasil kurniasih \& sari (2014) hal ini terjadi karena semakin tinggi nilai leverage dalam perusahaan, maka akan semakin tinggi pula tingkat agresivitas pajak pada perusahaan tersebut. Perusahaan yang memiliki beban pajak tinggi dapat melakukan penghematan pajak dengan cara menambah hutang perusahaan dan guna memperoleh intensif pajak yang besar.

Pengaruh variabel kontrol capital intensity tidak berpengaruh dengan signifikan lebih dari 0,05. Arah negatif menunjukkan bahwa perusahaan yang mempunyai aset tetap yang tinggi menanggung beban pajak yang tinggi. Capital intensity yang tidak berpengaruh terhadap ETR mengindikasikan bahwa perusahaan yang dijadikan sampel dalam penelitian mayoritas menginvestasikan modalnya pada persediaan(Hanum \& Zulaikha, 2013).

Pengaruh variabel kontrol inventory intensity tidak berpengaruh signifikan dengan hasil lebih dari 0,05. Banyak sedikitnya intensitas persediaan yang dimiliki perusahaan bukan merupakan faktor untuk menentukan besar kecilnya jumlah pajak yang dibayar perusahaan(Lestari, 2015). Intensitas persediaan tidak dapat memberikan dampak yang baik bagi perencanaan pajak yang dilakukan perusahaan, hal tersebut didukung adanya political cost theory yang mengartikan bahwa ketika laba perusahaan tinggi berarti nilai perusahaan tersebut akan menjadi sorotan pemerintah untuk mengambil keputusan seperti halnya mengambil pajak atas perusahaan tersebut. Intensitas persediaan menyebabkan bertambahnya pajak yang dibayar, yang berarti intensitas persediaan tidak dapat dikaitkan dengan manajemen pajak karena perusahaan akan lebih memilih berinvestasi pada aset tetap yang mana ada beban penyusutan yang dapat dikurangkan.

\section{Kesimpulan}

Penelitian yang ditujukan untuk menganalisis pengaruh pengungkapan Corporate Social Responsibility terhadap agresivitas pajak menunjukkan hasil sebagai berikut. (1) CSR tidak berpengaruh terhadap ETR artinya kegiatan CSR perusahaan tidak mempengaruhi perusahaan agar perusahaan membayarkan beban pajak perusahaan yang lebih kecil dikarenakan perusahaan yang bertanggung jawab sosial melakukan lebih sedikit kegiatan perencanaan pajak dibandingkan yang tidak bertanggung jawab secara sosial. (2) variabel kontrol ROA, capital intensity, dan inventory intensity tidak berpengaruh signifikan terhadap agresivitas 
pajak dikarenakan memiliki signifikan lebih dari 0,05\%. Variabel kontrol leverage berpengaruh terhadap agresivitas pajak dengan menunjukkan signifikansi kurang dari 0,05, sehingga diketahui variabel leverage berpengaruh signifikan.

\section{Referensi}

Fionasari, D., Savitri, E., \& Andreas. (2017). Pengaruh Pengungkapan Corporate Social Responsibility terhadap Agresivitas Pajak (Studi pada Perusahaan yang Listing di Bursa Efek Indonesia). Sorot, Volume 12(nomor 2), 95-105. doi: https://doi.org/10.31258/sorot.12.2.4557

Freedman, J. (2003). Tax and corporate responsibility. Tax journal, 1-4.

Ghozali, I. (2013). Aplikasi Analisis Multivariate dengan Program SPSS. Semarang: Badan Penerbit Universitas Diponegoro.

Gupta, S., \& K, N. (1997). Determinants of the variability on corporate effective tax rates: Evidence from longitudinal data. Journal of Accounting and Public Policy, 1-34.

Hadi, N. (2011). Corporate Social Responsibility. Yogyakarta: Graha Ilmu.

Hanum, H. R., \& Zulaikha. (2013). Pengaruh Karakteristik Corporate GovernanceTerhadap Effective Tax Rate. Diponegoro Journal OfAccounting, 1-10.

Indonesia, K. K. R. (2019). APBN 2019 Retrieved 3 Oktober 2020, from https://www.kemenkeu.go.id/apbn2019

Jessica, \& Toly, A. A. (2014). PENGARUH PENGUNGKAPAN CORPORATE SOCIAL. TAX \& ACCOUNTING REVIEW, VOL. 4, NO.1, 2014.

Kurniasih, T., \& Maria M., R. S. (2014). Pengaruh ROA, Leverage, Corporate Governance, Ukuran Perusahaan dan kompensasi rugi fiskal terhadap agresivitas pajak. TAX \& ACCOUNTING REVIEW, VOL. 4.

Kurniawan, A. W., \& Puspitaningtyas, Z. (2016). Metode Penelitian Kuantitatif (Cetakan Pertama ed.). Yogyakarta: Pandiva Buku.

Lanis, R., \& Richardson, G. (2012). Corporate social responsibility and tax aggressiveness: An empirical analysis. J. Account. Public Policy 31, 86-108.

Lestari, D. (2015). Pengaruh corporate governance dan intensitas persediaan dan keberadaan risk management comittee terhadap agresiitas pajak Jom FEKON Vol.2

Makhfudloh, F., Herawati, N., \& Wulandari, A. (2018). Pengaruh corporate social responsibility terhadap perencanaan agresivitas pajak. Jurnal Akuntansi dan Bisnis Vol 18 No 1, 48-160.

Nurcahyono, \& Kristiana, I. (2019). Pengaruh Corporate Social Responsibility (CSR) Terhadap Agresivitas Pajak: Studi Empiris pada Perusahaan Pertambangan yang Terdaftar di BEI Tahun 2017. Maksimum Media Akuntansi Universitas Muhammadiyah Semarang, Vol.9(No.2), 117-125.

Pradnyadari, I. D. A. I., \& Rohman, A. (2015). Pengaruh Pengungkapan Corporate Social Responsibility Terhadap Agresivitas Pajak. Diponegoro Journal Of Accounting, Vol..4(No. 2), 1-9.

Ross, S. A. (1977). The Determination of Finacial Structure:The Incentive Signalling Approach. Journal of Economics, 23-40.

Saputro, B. A. (2019, 3 Oktober 2020). Satu Dekade Target Pajak Tak Tercapai Retrieved 6 Juni 2020

Sudana, I. M., \& Airlindania, P. A. (2011). Corporate Governance Dan Pengungkapan Corporate Social Responsibility Pada Perusahaan Go-Public Di Bursa Efek Indonesia. Jurnal Manajemen Teori dan Terapan, No. 1.

Utomo, S. (2019). Laporan Kinerja Direktorat Jenderal Pajak. In K. K. R. Indonesai (Ed.). Jakarta: Laporan Kinerja

Wiguna, I. P. P., \& Jati, I. K. (2017). Pengaruh Corporate Social Responsibility, Preferensi Risiko Eksekutif, Dan Capital Intensity Pada Penghindaran Pajak. E-Jurnal Akuntansi Universitas Udayana, Vol.21(1), 418-446. 